IJMS 25 (1), 83-104 (2018)

\title{
DETERMINANTS OF ACCOUNTING-BASED PERFORMANCE: EVIDENCE FROM BURSA MALAYSIA
}

\author{
RUSMAWATI ISMAIL \\ NUR ADIANA HIAU ABDULLAH \\ KAMARUN NISHAM TAUFIL MOHD \\ School of Economics, Finance and Banking \\ UUM College of Business \\ Universiti Utara Malaysia
}

\begin{abstract}
This study aims to examine the determinants of the accounting-based performance of 531 non-financial Malaysian listed companies over the period 2004 to2012. The system generalized method of moments reveals that both prior risk-taking behaviour and size are found to be important determinants of performance. A significant positive influence of prior risk-taking behaviour on performance implies that risk-averse managers are cognitively influenced by their capability in handling risky investments in the past; consequently enhance confidence in their ability to manage profitable investments. The result appears to support the capital asset pricing model implication. Meanwhile, a significant positive size-performance relationship suggests that investors and fund managers should focus on larger companies as they can have better stock performance.
\end{abstract}

Keywords: Risk-return relationship, reverse size effect, System-GMM.

Received: $1 / 10 / 2017$

Revised: 4/02/2017

Accepted: 28/2/2018

\section{Introduction}

Financial performance is considered as an effective indicator of a company's achievement over its fiscal year. Return on asset (ROA) is one of the most favorable accounting-based performance measures (Al-Matari, Al-Swidi, \& Fadzil, 2014; Issah \& Antwi, 2017), which reflects the fundamentals of business, including the effectiveness of wealth-generating activities by means of assets utilization. In view of this fact, ROA could be considered as one of the essential 
components of financial performance measures which can encourage people to invest in a company. As such, corporate managers should take strategic actions to genuinely improve this accounting-based performance from time to time.

The issue on the determinants of corporate financial performance has long been discussed in the areas of financial economics (Hodoshima, Garza-Gomez, \& Kunimura, 2000; Blitz \& Van Vliet, 2007; Rossi \& Timmerman, 2012; Vintila \& Nenu, 2015) and strategic management (McNamara \& Bromiley, 1999; Andersen, Denrell, \& Bettis, 2007; Henkel, 2009; Li, Yang \& Zhang, 2014). Identification of factors that can accurately predict firm performance is of great interest to any decision maker. Many studies (Hawawini, Subramanian, \& Verdin, 2003; Issah \& Antwi, 2017) argue that industry-specific (external) factors play a more important role in dictating the influence of firm performance. On the other hand, other studies (Opler \& Titman, 1994; Kamasak, 2011) suggest that firm specific (internal) factors seem to be the major determinants of firm performance, and are the main drivers of competitive advantage which is crucial for the longrun survival of a company. Focusing on firm specific factors seems more appropriate for this study since prior research documented that a firm's characteristic factors had a greater effect in explaining firm performance as compared to industry effects (Hansen \& Wernerfelt, 1989; Yurtoglu, 2004).

Several research papers (Chandrapala \& Knápková, 2013; Kaya, 2015; Ismail \& Subramaniam, 2017) developed a measurement model for firm performance based on various internal indicators. Chandrapala and Knápková (2013) investigated the impact of eight internal factors on ROA of 974 firms in the Czech Republic over the period 2005 to 2008. The study showed that firm size, sales growth and capital turnover had significant positive impacts on the financial performance of firms. Meanwhile, debt ratio and inventory reflected significant negative impacts on the financial performance of firms. Furthermore, Kaya (2015) investigated the firm-specific factors affecting the profitability of 24 non-life insurance companies operating in Turkey over the period 2006 to 2013. The main results of the study demonstrated that profitability of non-life insurance companies was statistically significant and positively related to the size of a company and the premium growth rate, whereas profitability was statistically significant and negatively related to the age of a company, loss ratio 
and current ratio. A similar study was conducted by Ismail and Subramaniam (2017) on 42 consumer product companies in Malaysia for the period 2006 to2015. The results suggest that sales growth (debt to equity ratio) is positively (negatively) and significantly related to profitability.

However, despite being a highly debated topic in the literature, previous studies have not reached a conclusive inference with regard to which company-specific factors most affect the performance of a company. Inconclusive results will impinge investors' strategy to secure the best investment opportunities with maximum returns for a given level of risks. Therefore, it provides an avenue for the current research to test the previously examined factors and integrate behavioural models of decision-making, agency theory and other relevant theoretical views into the research framework. A blend of a broader set of organisational theories could give a better explanation on the risk-return relationship, which can add value to the body of knowledge on this issue in the context of emerging markets.

The Malaysian stock market is of special interest as Morgan Stanley Capital International (MSCI) views it as one of the emerging markets in the Asian region which could offer a good place for investment ${ }^{1}$ (Lingaraja, Selvam \& Vasanth, 2014). Even though comparatively an emerging market, Malaysia was claimed to be efficient during the period of 2004 to 2013 in the Asian region (Lingaraja et al., 2014), the profile of risk and return in this market may be different from those of efficient markets in developed countries. This is because emerging markets and developed markets do not have similar characteristics (Bekaert, Erb, Harvey \& Viskanta, 1998; Bekaert \& Harvey, 2002; Bekaert \& Harvey, 2003).

This study focuses on both the lagged and contemporaneous risktaking, size, financial slack and leverage as company-specific factors are expected to have influence on accounting-based performance. To the author's knowledge, this is the first attempt to utilize the generalized method of moments (GMM) estimator in investigating

1 By having sound domestic macroeconomic fundamentals, ample liquidity of financial markets and good banking systems enable Malaysia to have sufficient buffers against external shocks, namely USA sub-prime financial crisis and European sovereign debt crisis (Abidin \& Rasiah, 2009; Ibrahim, 2010; Samsi, Yusof \& Cheong, 2012). 
the determinants of corporate performance within the context of the Malaysian market. By using the system generalized method of moments (S-GMM) which is claimed to be as robust in the class of all GMM estimators, this paper could offer a better explanation of the issue discussed.

Conventionally, decision-makers are assumed to be prone to riskaverse behaviour (Jensen, 1986; Coffee, 1988; Gomez-Mejia \& Wiseman, 1997). Apparently, this behaviour will lead to positive riskreturn relationships (Fisher \& Hall, 1969; Hurdle, 1974; Brealey \& Myers, 2003). This risk preference is deemed to be compatible with the settings of an efficient market wherein assets are priced with the aim that their expected return will compensate shareholders for their expected risk. However, the empirical issue of Bowman's paradox has been widely discussed in Western countries since Bowman's (1980) seminal work denies the standard assumption of a positive risk-return relationship and risk-averse behaviour derived from the CAPM theory.

Many management scholars empirically prove risk-seeking behaviour amongst manager leads to negative risk-return relationship (Bromiley, 1991; Fiegenbaum \& Thomas, 1985, 1986, 1988; Wiseman \& Bromiley, 1991). This phenomenon emerges as the management team of a poorly performed company is willing to bear higher risks, and do not mind accepting lower returns as long as the company has an opportunity to get out of an unfavourable situation. The temptation to engage in risk-seeking behaviour reflects the perspective of Tversky is (1990) irrational behaviour of organisational decision-makers in making investment decisions. Behavioural finance suggests that the decision-makers' risk preference is affected by several cognitive and psychological errors (Ritter, 2003). Apparently, anomaly in risk preference contradicts the core assumption of efficient market hypothesis (EMH). The paradox in accounting-based risk-return relationship remains unexplained as Oviatt and Bauerschmidt (1991) failed to detect any significant relationship between risk and return based on three-stage least squares (3SLS) estimates. In addition, Chang and Thomas (1989) documented both positive (managers tend to pursue risky investments as they experience certain levels of higher returns) and negative relationships (managers also tend to gamble on risky investments as they experience certain levels of lower returns) or a curvilinear risk-return relationship. 
The observation of inverse relationship between the size of companies and performance, which is labelled as size effect was first documented by Banz (1981) and Reinganum (1981). Based on the US market data, they suggested that excess returns would have been earned by holding stocks of small sized companies. The finding on this issue was further supported by Fama and French (1992). Amel-Zadeh (2011) validated the existence of size effect in the Germany equity market. He suggested that the impact of company size on stock returns is conditional on market situation where in the bearish (bullish) market, smaller (larger) companies outperform larger (smaller) companies.

However, evidence on the issue of size effect has not always been one-sided. For example, studies based on data from the US (Chang \& Thomas, 1989; Horowitz, Loughran \& Savin, 2000; Schwert, 2003; Chaibi, Alioui \& Xiao, 2014), Korea (Mukherji, Dhatt, \& Kim, 1997), UK (Dimson \& Marsh, 1999; Dimson, Marsh \& Staunton, 2002), Nigeria (Muritala, 2012), Tanzania (Kipesha, 2013), Czech Republic (Chandrapala \& Knápková, 2013), Turkey (Kaya, 2015) and Malaysia (Mohd Ali, 2006) suggest that small sized companies have substantially lower returns than large sized companies. These researches show that the reversed size effect does not only happen in emerging markets but also exists in mature markets. Schwert (2003) suggests that the size effect appears to be reversed because practitioners begin to utilize investment tools which enable them to exploit the small-firm anomaly for their portfolio maximisation. Some studies have shown that large firms have a direct impact on performance due to the ability in operating business efficiently (Kumar, 2004; Bos \& Kolari, 2005; Van Biesebroeck, 2005; Aljifri \& Moustafa, 2007), utilizing economies of scales and dominating the market (Bain, 1954; Kumar, 2004; Serrasqueiro \& Macas Nunes, 2008), experiencing more business diversification (Yang \& Chen, 2009), having greater financial resources (Arora \& Gambardella, 1990) and diversifying risk efficiently (Ghosh, 1998; Bossone \& Lee, 2004).

The issue on financial slack-performance relationship in developed markets has been investigated from the perspective of the behavioural theory of the firm and the agency theory. The proponents of the behavioural theory of the firm and the agency theory posit contradictory hypothesis on the influence of financial slack on a firm's performance (Daniel, Lohrke, Fornaciari \& Turner, 2004). From the perspective of the behavioural theory of the firm, financial slack is excess resource that can be utilized to absorb variation in the external business environment and tackle problems that may threaten the company's survival (Sharfman, 
Wolf, Chase, \& Tansik, 1988). In addition, financial slack resource can be used to take advantage of environmental opportunities and pursue innovative activities (Cyert \& March, 1963; Sang, Hyuksoo, \& Hinh, 2014). Therefore, organisational decision-makers need to be proactive in order to facilitate environmental change (Cheng \& Kesner, 1997). These arguments support the positive effect of financial slack on performance of a company (Cyert \& March, 1963; Pfeffer \& Salancik, 1978; Marlin \& Geiger, 2015). In line with this contention, many researchers argue that financial slack is necessary to ensure the long-run survival of a company (Singh, 1986; Hambrick \& D'Aaveni, 1988; Lee, 2011).

In contrast, from the perspective of corporate governance issue, agency theorists typically argue that without effective monitoring of management, financial slack provides extra costs and inefficiency to the company and thus harms its performance (Jensen \& Meckling, 1976; Fama, 1980; Jensen, 1986). This is because organisational decision-makers who are described as self-centred agents would have a tendency to waste the extra financial resources for the purpose of seeking their own interest at the expense of shareholders. Therefore, many scholars are in agreement that financial slack should be reduced to minimize the possibility of mismanagement which can cause performance to decline (Davis \& Stout, 1992; Phan \& Hill, 1995; Steensma \& Corley, 2000).

A number of previous literature has shown that corporate governance mechanisms are important to be implemented in order to promote a more transparent and effective decision-making criteria for the management to act in the best interest of the shareholders (Tirole, 2001; Al-Faki, 2006). In the context of Jensen's (1986) free cash flow hypothesis, leverage is considered as one of the governance mechanisms which can reduce the opportunistic behaviour of managers in over-investing the financial resources under their control at the expense of shareholders. The proponents of the free cash flow hypothesis argue that having greater debt financing leads managers to put more efforts in managing risky projects that have greater potential for larger returns. Failure to meet debt payment will expose the company to bankruptcy problems (Altman, 1993), which in turn may cause the threat of manager replacement (Jensen, 1989). Thus, the existence of such a governance mechanism would mitigate the manager-shareholder conflict of interest which, in turn, could improve shareholders' values (Jensen, 1986; Harris \& Raviv, 1991). Evidence of the free cash flow hypothesis is further supported by a 
number of researchers (see for example, Campello, 2006; Berger \& Bonaccorsi di Patti, 2006; Franck, Huyghebaert, \& D’Espallier, 2010). The organisation of the rest of this paper is as follows. Section 2 describes how the present study is practically carried out. In Section 3 , the results of the study are presented. Finally, Section 4 summarises the findings and highlights the implications of the study.

\section{Methods}

The empirical test of this study was based on 531 non-financial Malaysian listed companies. An unbalanced panel data was collected for nine years from 2004 to 2012. This period of study was selected because the Malaysian stock market was claimed to be relatively efficient as compared to its counterparts in the Asian region during that period (Lingaraja, Selvam \& Vasanth, 2014). All annual based data set for this study were extracted from Datastream. The purpose of relying on a single source of database was to ensure consistency of extracted data. The uniformity of the data was expected to result in an unbiased analysis. To answer the research objective of this study, the following model was examined.

$$
\begin{aligned}
\text { PERFroa }_{i, t}= & \alpha_{0}+\alpha_{1} \text { RISKSTDroa }_{i, t-1}+\alpha_{2} \text { RISKSTDroa }_{i, t}+\alpha_{3} \text { SIZE }_{i, t}+ \\
& \alpha_{4} \text { FSlack }_{i, t}+\alpha_{5} \text { LEV }_{i, t}+\alpha_{6} \text { PERFroa }_{i, t-1}+e_{i, t}
\end{aligned}
$$

where, $\mathrm{i}=1, \ldots, N$ represents the company and $\mathrm{t}=1, \ldots, T$ represents time period. Dependent variable PERFroa $_{i^{\prime} t}$ represents company $i^{\prime} \mathrm{s}$ performance. The company-specific variables, namely RISKSTDroa ${ }_{i, t-1}$ and RISKSTDroa ${ }_{i, t}$ represent risk-taking in year $t-1$ and $t$ respectively; $S I Z E_{i, t}$ refers to company $i$ 's size (measured by total assets) in year $t$; FSlack $_{\mathrm{i}, \mathrm{t}}$ is financial slack (measured by current ratio) for company $i$ in year $t$; and $\operatorname{LEV}_{i, t}$ is company $i$ 's debt-to-equity ratio in year $t$. Time dummies are included in the specification (where appropriate) and SIZE $_{i, t}$ is transformed into logarithms. It is assumed that the error terms $e_{i, t}$ in the above equation follow a one-way error component model:

$$
e_{i, t}=\lambda_{i}+v_{i, t}
$$

where $\lambda_{\mathrm{i}} \sim i i d\left(0, \sigma^{2} \lambda\right)$ represents the specific effects and $\boldsymbol{\nu}_{\text {it }} \sim$ iid $\left(0, \sigma^{2} v\right)$ is the error term. They are independent of each other and among themselves. 
This research applies one of the most common variations of GMM to estimate the dynamic unbalanced panel models. The method is known as system-GMM (S-GMM) estimator (Arellano \& Bover, 1995; Blundell \& Bond, 1998; 2000). This dynamic panel data estimation approach is an extension of the original GMM estimator from Arellano and Bond (1991), which is known as the difference-GMM (D-GMM) estimator. The basic principle of the D-GMM is to eliminate the unobserved individual-specific effects by accomplishing firstdifferenced equations with suitable lagged levels of the dependent and endogenous variables as instruments. However, implementing first differencing lessens the variation in all regressors which leads to weak identification problems and increases measurement errors. Therefore, the S-GMM was employed.

The S-GMM method combines moment conditions for model in first differences (the transformed equation) with moment conditions for the model in levels (the original equation). This process is done by exploiting lagged variables at levels as instrumental variables in the transformed equation whereas lagged difference variables are used as instruments in the original equation. By estimating regressions in the transformed and original equations simultaneously, the S-GMM is able to differentiate the instruments while keeping regressors in levels. Hence, this procedure allows the introduction of more instruments, further reduce the finite sample bias and substantially improves the estimation efficiency (Blundell, Bond, \& Windmeijer, 2000; Windmeijer, 2005; Roodman, 2006; Baltagi, 2008). The consistency and reliability of the GMM estimator procedures were tested using two standard diagnostic tests. The over-identifying restriction was tested using the Sargan's (1964) test of misspecification, meanwhile the Arellano-Bond (1991) tests for first order serial correlation (AR(1)) and second order serial correlation $(\mathrm{AR}(2))$ of the residuals were applied to verify the efficiency of model estimations using the GMM approach.

The S-GMM estimation procedure is performed in one- and twostep variants. The process starts by calculating the one-step GMM estimates. In the first step, homoskedasticity and independent residuals are assumed. Then, by utilizing the one-step residuals, a more efficient two-step GMM estimator is computed. The two-step S-GMM estimation method is credited as a more sophisticated and effective approach since this estimator uses optimal weighting matrices. Furthermore, Windmeijer (2005) proposes a two-step estimator with robust standard errors to correct finite-sample bias. The adjustment 
is performed by acquiring an estimated variance covariance matrix (VCE) which is robust to heteroskedasticity. This adjustment will not change the point estimates. Only estimated VCE and standard errors are changed. By doing the correction of the standard errors of the two-step GMM estimates, this estimator is more competent in dealing with the issues of endogeneity for some of the explanatory variables and omitted variables bias. Most importantly, this method is capable of offering acceptable and consistent estimators for the above mentioned issues.

\section{Results}

Table 1 presents the summary of the descriptive statistics for each continuous variable used in the study over the period 2004 to 2012. The number of observations depicted in Table 1 depends on the availability of the data provided by Datastream. Thus, the total number of observations for company specific characteristics is not equal to 4779 company-year observations. The findings of the descriptive analysis represent both the 388 active companies and the 143 delisted companies categorized under all non-financial sectors. This has caused a huge gap between the minimum and maximum values of all variables. The blend of both active and delisted companies is meant to create a survivorship-bias-free data set.

Table 1

Descriptive Statistics of Continuous Variables over the Period 2004-2012

\begin{tabular}{lccccc}
\hline & $\begin{array}{c}\text { Obs } \\
(\mathrm{N})\end{array}$ & Mean & STD & Min & Max \\
\hline PERFroa $_{i, t}(\%)$ & 4109 & 3.33 & 12.36 & -99.90 & 107.70 \\
PERFroa $_{i, t-1}(\%)$ & 3726 & 3.24 & 12.58 & -104.28 & 111.95 \\
RISKSTDroa $_{i, t}(\%)$ & 3711 & 5.64 & 7.49 & 0.20 & 58.51 \\
RISKSTDroa $_{i, t-1}(\%)$ & 3335 & 5.73 & 7.60 & 0.20 & 59.35 \\
SIZE $_{i, t}{ }^{3}($ Total Assets & 4134 & 1195697 & 2311269 & 1172 & 11100000 \\
in RM'000) $_{\text {FSlack }_{i, t}(\%)}$ & 4074 & 2.42 & 2.49 & 0.01 & 12.43 \\
LEV $_{i, t}$ & 4128 & 0.67 & 1.79 & -11.41 & 12.91 \\
\hline
\end{tabular}

The results of pairwise Pearson's correlation for the research model are depicted in Table 2. Generally, almost no multicollinearity 
problem arises between the independent variables in the predictive model. This is because the pairwise Pearson's correlation indicators for almost all independent variables are less than 0.8. Table 2 shows that only RISKSTDroa $a_{i, t}$ has a pairwise Pearson's correlation that exceeds 0.8 . Therefore, to ensure there is no multicollinearity problem amongst the paired variables, the variance inflation factor (VIF) is applied. Hair et al. (2010) suggested that a VIF of less than 10 would indicate that no serious multicollinearity problem exists. The results in Table 3 confirm that there is no threat of multicollinearity as all variables presents VIF below 10.

Table 2

Pearson Correlation Tests between Independent Variables of Study

\begin{tabular}{|c|c|c|c|c|c|c|}
\hline $\begin{array}{l}\text { Independent } \\
\text { variables }\end{array}$ & RISKSTDroa $a_{i,-1}$ & RISKSTDroa $_{i, t}$ & $S I Z E_{i, t}$ & FSlack $_{i, t}$ & $L E V_{i, t}$ & PERFroa $_{i, t-1}$ \\
\hline RISKSTDroa $_{i, t-1}$ & 1.00 & & & & & \\
\hline RISKSTDroa $_{i, t}$ & $0.87^{* *}$ & 1.00 & & & & \\
\hline$S I Z E_{i, t}$ & $-0.23^{* *}$ & $-0.26^{* *}$ & 1.00 & & & \\
\hline FSlack $_{i, t}$ & $-0.04^{*}$ & $-0.05^{* *}$ & $-0.07^{* *}$ & 1.00 & & \\
\hline$L E V_{i, t}$ & $-0.07^{* *}$ & $-0.07^{* *}$ & $0.13^{* *}$ & $-0.17^{* *}$ & 1.00 & \\
\hline PERFroa $_{i, t-1}$ & $-0.18^{* *}$ & $-0.15^{* *}$ & $0.22^{* *}$ & $0.14^{* *}$ & 0.003 & 1.00 \\
\hline $\begin{array}{l}\text { Notes. }{ }^{* *} \text { and } \\
\text { Table } 3\end{array}$ & indicate the 1 & 6 and $5 \%$ sig & ificanc & level re & spectiv & ly. \\
\hline \multicolumn{7}{|c|}{ Variance Inflation Factor (VIF) for Multicollinearity Assumption of Model } \\
\hline \multicolumn{3}{|c|}{ Independent variables } & \multicolumn{4}{|c|}{ VIF } \\
\hline \multicolumn{3}{|c|}{ RISKSTDroa $_{i, t-1}$} & \multicolumn{4}{|c|}{3.97} \\
\hline \multicolumn{3}{|c|}{ RISKSTDroa $_{i, t}$} & \multicolumn{4}{|c|}{3.98} \\
\hline \multicolumn{3}{|c|}{$S I Z E_{i, t}$} & \multicolumn{4}{|c|}{1.09} \\
\hline \multicolumn{3}{|c|}{ FSlack $_{i, t}$} & \multicolumn{4}{|c|}{1.04} \\
\hline \multicolumn{3}{|c|}{$L E V_{i, t}$} & \multicolumn{4}{|c|}{1.05} \\
\hline
\end{tabular}


IJMS 25 (1), 83-104 (2018)

Since the financial econometric issue discussed in this study is dynamic by nature, the dynamic panel data analysis by using the generalized method of moments (GMM) estimator was applied. The standard diagnostic tests of dynamic System-GMM (S-GMM) estimator presented in Table 4 reveals that the research model which is found in the accounting-based data fulfills the statistical properties.

Table 4

Diagnostic Test

\begin{tabular}{|c|c|c|c|c|}
\hline & $\begin{array}{c}\text { One-step } \\
\text { S-GMM } \\
(1)\end{array}$ & $\begin{array}{l}\text { Two-step } \\
\text { S-GMM } \\
(2)\end{array}$ & $\begin{array}{c}\text { Two-step S-GMM } \\
\text { with robust SE } \\
\text { (3) }\end{array}$ & $\begin{array}{c}\text { Two-step } \\
\text { S-GMM with } \\
\text { time dummies } \\
\text { and Maxldep } \\
\text { (4) }\end{array}$ \\
\hline \multicolumn{5}{|c|}{$\begin{array}{c}\text { PERFroa }_{i, t}=\alpha_{0}+\alpha_{1} \text { RISKSTDroa }_{i, t-1}+\alpha_{2} \text { RISKSTDroa }_{i, t}+\alpha_{3} \text { SIZE }_{i, t}+\alpha_{4} \text { FSlack }_{i, t} \\
+\alpha_{5} \text { LEV }_{i, t}+\alpha_{6} \text { PERFroa }_{i, t-1}+e_{i, t}\end{array}$} \\
\hline $\begin{array}{l}\text { Sargan test } \\
\text { of over- } \\
\text { identifying } \\
\text { restrictions } \\
\text { (p-value) }\end{array}$ & $\begin{array}{l}172 . \\
(0.00)\end{array}$ & $\begin{array}{l}50.95 \\
(0.03)\end{array}$ & - & $43.76(0.06)$ \\
\hline $\begin{array}{l}2^{\text {nd }} \text { order } \\
\text { autocorrelation } \\
\text { Test (p-value) }\end{array}$ & - & $\begin{array}{c}1.23 \\
(0.22)\end{array}$ & $1.18(0.24)$ & $1.35(0.18)$ \\
\hline \# of lags & - & - & - & 5 \\
\hline $\begin{array}{l}\text { \# of } \\
\text { instruments }\end{array}$ & 41 & 41 & 41 & 46 \\
\hline \# of groups & 500 & 500 & 500 & 500 \\
\hline
\end{tabular}

In line with Arellano and Bond's (1991) findings, column (1) of Table 4 shows that the one-step S-GMM version of the Sargan-test is sensitive to heteroskedasticity ( $p$-value is less than 0.05 ), leading to rejection of the validity of instruments for the model. Due to the presence of heteroskedasticity of unknown form, the results of repeated Sargantest analysis based on two-step GMM (column 2), two-step GMM estimators with robust standard error (column 3), and two-step 
S-GMM with time dummies which includes $p$ lags of dependent variable (column 4 ) are then presented. The result shows that the twostep S-GMM with time dummies and $p$ lags of dependent variable is regarded as the final estimator. This is because the higher p-value of the Sargan statistic (p-value is greater than 0.05) reflects that the instruments are exogenous and the model is appropriate. Therefore, the result suggests that this model is well specified and the estimators chosen are consistent.

Another important diagnostic test in dynamic panel data estimation is the Arellano-Bond (1991) test for autocorrelation between residuals (AR). This diagnostic test is employed to check the validity of instruments due to the dynamic nature of data (Arellano \& Bond, 1991). Overall, the results of the diagnostic test AR(2) reported in Table 4 meet the requirements of accepting no second order serial correlation in the first-difference residuals (all respective $\mathrm{p}$-values are greater than 0.05).

Table 5 documents that lagged corporate risk-taking (RISKSTDroa ${ }_{i, t-1}$ ) has a positive and significant influence on contemporaneous accounting performance. The coefficient of regressing PERFroa ${ }_{i, t}$ on RISKSTDroa ${ }_{i, t-1}$ is $0.47(\mathrm{z}=3.50)$ and it is significant at the 99 percent confidence level. The estimated coefficient implies that a one percentage point increase in RISKSTDroa ${ }_{i,-1}$ tends to increase the PERFroa ${ }_{i, t}$ by 0.47 percentage point. The relationship between these two variables is commonly discussed in industrial organisation economics and strategic management. The results imply that corporate decision-makers in Malaysia engage in risk-averse behaviour when they expect this behaviour to bring in higher returns. In line with the risk-averse preference, managers are sensitive to the past accounting-based risk taking indicators as a basis for matching their response towards securing a safer investment (Teece, Pisano, \& Shuen, 1997). Consequently, high accounting returns are expected in order to compensate for taking additional risks in the past. The above argument explains the existence of a significantly positive correlation between prior risk-taking and subsequent performance in the Malaysian listed companies. The finding confirms that the effect of risk on returns is not immediate but gradually realized over time (Abdullah et al. 2017). 
IJMS 25 (1), 83-104 (2018)

Table 5

The Impact of Company-specific Factors on Accounting-based Performance

\begin{tabular}{lc}
\hline Corporate Performance Indicator & PERFroa $_{i, t}$ \\
\hline Constant & $-84.84(-5.44)^{* * *}$ \\
Lagged corporate risk-taking $\left(\right.$ RISKSTDroa $\left._{i, t-1}\right)$ & $0.47(3.50)^{* * *}$ \\
Contemporaneous corporate risk-taking & $-0.28(-1.82)^{*}$ \\
$\left(\right.$ RISKSTDroa $\left._{i, t}\right)$ & \\
Total assets $\left(\right.$ SIZE $\left._{i, t}\right)$ & $6.48(5.48)^{* * *}$ \\
Current ratio $\left(\right.$ FSlack $\left._{i, t}\right)$ & $0.48(1.90)^{*}$ \\
Debt-to-equity ratio $\left(\right.$ LEV $\left._{i, t}\right)$ & $0.002(0.70)$ \\
Lagged dependent variable $\left(\right.$ PERFroa $\left._{i, t-1}\right)$ & $0.21(9.90)^{* * *}$ \\
Sargan test of over-identifying restrictions (p-value) & Pass \\
$2^{\text {nd }}$ order autocorrelation Test (p-value) & Pass \\
Company-year observation & 3141 \\
T & 9 \\
\hline
\end{tabular}

Notes. (1) Only the final models are reported; (2) The lagged dependent variable used as explanatory variables in this model is positive and has a highly significant effect (at 99\% confidence level), implying that the model is genuinely dynamic; (3) ${ }^{* * *}$ and ${ }^{* *}$ indicate $1 \%$ and $5 \%$ significance level respectively.

The dynamic panel estimation also reveals that the estimated coefficient of company size $\left(S I Z E_{i, t}\right)$ on performance is statistically positive and significant at the 99 percent confidence level, indicating that one percentage point increase in $S I Z E_{i, t}$ would be reflected in 0.0648 percentage point increase in $P E R F r o a_{i, t}$. The positive relationship is consistent with the findings of past studies (Chang \& Thomas, 1989; Majumdar, 1997; Mukherji et al., 1997; Dimson et al., 2002; Schwert, 2003; Mohd Ali, 2006; Aljifri \& Moustafa, 2007; Yang \& Chen, 2009; Saliha \& Abdessatar, 2011; Muritala, 2012; Kipesha, 2013; Chaibi et al., 2014; Akben-Selcuk, 2016) hence, it verifies the importance of size in influencing the performance of the Malaysian listed companies. The result also reported that corporate performance is negatively (positively) afffected by RISKSTDroa ${ }_{i, t}\left(\right.$ FSlack $\left._{i, t}\right)$, but the relationship is only marginally significant at the 90 percent confidence level. The former relationship appears to weakly support the argument made by previous studies (Bowman, 1980; Bettis \& Hall, 1982; Whitelaw, 1994; Ang et al., 2006; Banerjee, Doran, \& Peterson, 2007; Boermans \& Willebrands, 2012) that contemporaneous risk has adverse effect 
on contemporaneous performance. Meanwhile, the latter relationship is consistent with the implication stated in the behavioral theory of the firm as promoted by Cyert and March (1963) where the greater the financial slack, the better the performance of companies (Pfeffer \& Salancik, 1978; Marlin \& Geiger, 2015). However, leverage $\left(L E V_{i, t}\right)$ is reported to have no influence on corporate performance. The insignificant relationship denies the implication stated in Jensen's (1986) free cash flow hypothesis, which maintains that greater debt financing would reduce the opportunistic behavior of managers at the expense of shareholders (Campello, 2006; Berger \& Bonaccorsi di Patti, 2006; Franck, Huyghebaert, \& D’Espallier, 2010).

\section{Conclusion}

This study investigated the factors contributing to the accountingbased performance of the Malaysian listed companies over the period of 2004 to 2012. The result of multiple regressions using S-GMM estimation reveals the existence of a significantly positive correlation between lagged corporate risk-taking and performance. This implies that corporate decision-makers of the Malaysian listed companies engage in risk-averse behaviour when they expect this behaviour leads to higher returns. The preference of a more certain outcome to a less certain one is in line with Sharpe's (1964) CAPM model, but appears to challenge Cyert and March's (1963) behavioral theory of the firm. However, when contemporaneous corporate risk-taking is considered, minimal negative impact on performance is recorded. This finding inclines to support Bowman's paradox (1980) which suggests that the risk preference amongst Malaysian economic agents is not static but vary in accordance with their past experience. The practical implication of the finding for managers is that, the role of prior risk-taking should be acknowledged as one of the corporate strategies to improve companies's performance. The dynamic panel estimation also verifies the importance of company size as one of the accounting-based corporate performance determinants. This would mean that investors and fund managers should focus on large firms as they are associated with higher performance. Furthermore, the finding of this research also reports the importance of financial slack as one of the contributing factors of corporate performance, but the presence of a positive effect is minor. With regard to policy implication to policymakers such as the Securities Commission (SC), the outcomes could furnish this regulatory body with a more accurate and reliable risk-return assessment model. Having a more 
relevant model can facilitate the regulator in disclosing a more comprehensive and relevant risk-return profile of listed companies. Better understanding and perception on the overall risk-return profile of listed companies is important so that this security market watchdog can regulate a more transparent risk-return information disclosure in companies' annual reports. Greater transparency would promote trust and confidence as well as protect the interest of investors and other stakeholders. As in other studies, there is a limitation to this study where the results are only applicable for the period from 2004 to 2012. Future research should lengthen the study period taking into account a more recent data set so as to capture the profile of riskreturn relationship before and after the financial crisis within the past two decades of the economic cycle. In addition, we have only used ROA as the performance measure. There would be other accounting and market-based measures that could represent performance such as return on equity and total return index. Future studies could compare which among the measures would best represent the performance of a company.

\section{References}

Abdullah, M. H. S. B., Janor, H., Hamid, M. A., \& Yatim, P. (2017). The effect of enterprise risk management on firm value: Evidence from Malaysian technology firms. Jurnal Pengurusan, 49. 3-11.

Akben-Selcuk, E. (2016). Factors affecting firm competitiveness: Evidence from an emerging market. International Journal of Financial Studies, 4(9). 1-10.

Al-Faki, M. (2006). Transparency and corporate governance for capital market development in Africa: The Nigerian case study. Securities Market Journal, 9-28

Aljifri, K., \& Moustafa, M. (2007). The impact of corporate governance mechanisms on the performance of UAE firms: An empirical analysis. Journal of Economic \& Administrative Sciences, 23(2), 7193.

Al-Matari, E.M., Al-Swidi, A.K., \& Fadzil, F.H. (2014). The measurements of firm performance's dimension. Asian Journal of Finance \& Accounting, 6(1), 24-49.

Altman, E. I. (1993). Corporate financial distress and bankruptcy. New York: John Wiley and Sons.

Amel-Zadeh, A. (2011). The return of the size anomaly: Evidence from the German stock market. European Financial Management, 17(1), 145-182. 
Andersen, T. J., Denrell, J., \& Bettis, R. A. (2007). Strategic responsiveness and bowman's risk-return paradox. Strategic Management Journal, 28, 407-429.

Ang, A., Hodrick, R. J., Xing, Y., \& Zhang, X. (2006). The cross-section of volatility and expected returns. The Journal of Finance, LXI(1), 259-299.

Arellano, M., \& Bond, S. (1991). Some tests of specification for panel data: Monte Carlo evidence and an application to employment equations. Review of Economic Studies, 58, 277-297.

Arellano, M., \& Bover, O. (1995). Another look at the instrumental variable estimation of error-components models. Journal of Econometrics, 68, 29-51.

Arora, A., \& Gambardella, A. (1990). Complementarity and external linkages: The strategies of the large firms in biotechnology. Journal of Industrial Economics, 38(4), 361-379.

Bain, J. S. (1954). Economies of scale, concentration, and the condition of entry in twenty manufacturing industries. The American Economics Review, 44(1), 15-39.

Baltagi, B. H. (2008). Econometric Analysis of Panel Data. (4th ed.). New York: Wiley.

Banerjee, P. S., Doran, J. S., \& Peterson, D. R. (2007). Implied volatility and future portfolio returns. Journal of Banking and Finance, 31, 3183-3199.

Banz, R. W. (1981). The relationship between return and market value of common stocks. Journal of Financial Economics, 9, 3-18.

Berger, A. N., \& Bonaccorsi di Patti, E. (2006). Capital structure and firm performance: A new approach to testing agency theory and an application to the banking industry. Journal of Banking E Finance, 30, 1065-1102.

Bettis, R. A., \& Hall, W. K. (1982). Diversification strategy, accountingdetermined risk, and accounting-determined return. Academy of Management Journal, 25, 254-264.

Blitz, D. C., \& Van Vliet, P. (2007). The volatility effect: Lower risk without lower return. Journal of Portfolio Management (Fall), 102113.

Blundell, R. W., \& Bond, S. R. (1998). Initial conditions and moment restrictions in dynamic panel data models. Journal of Econometrics, 87, 115-143.

Blundell, R., \& Bond, S. (2000). GMM estimation with persistent panel data: An application to production functions. Econometric Reviews, 19(3), 321-340.

Blundell, R., Bond, S., \& Windmeijer, F. (2000). Estimation in dynamic panel data models: Improving on the performance of the 
standard GMM estimator. In B. Baltagi (Ed.), Non-stationary panels, panel cointegration and dynamic panels, Elsevier Science. Retrieved from http://www.ifs.org.uk/wps/wp0012.pdf

Boermans, M., \& Willebrands, D. (2012) Financial Constraints, Risk Taking and Firm Performance: Recent Evidence from Microfinance Clients in Tanzania. DNB Working Paper, No. 358.

Bos, J. W. B., \& Kolari, J. W., (2005). Large bank efficiency in Europe and the United States: Are there economic motivations for geographic expansion in financial services? Journal of Business, 78(4), 1555-1592.

Bossone, B., \& Lee, J. K. (2004). In finance, size matters: The 'systemic scale economies' hypothesis. IMF Staff Papers, 51(1). Retrieved from http://www.imf.org/external/ pubs/ft/wp/2002/wp02113. pdf

Bowman, E. H. (1980). A risk/return paradox for strategic management. Sloan Management Review (Spring), 21, 317-31.

Brealey, R. A., \& Myers, S. C. (2003) Principles of corporate finance (7th ed.). Boston: McGraw-Hill, Irwin.

Bromiley, P. (1991). Testing a causal model of corporate risk taking and performance. The Academy of Management Journal, 34(1), 3759 .

Campello, M. (2006). Debt financing: Does it boost or hurt firm performance in product markets? Journal of Financial Economics, $82,135-172$.

Chaibi, A., Alioui, S., \& Xiao, B. (2014). On the impact of firm size on risk and return: Fresh evidence from the American stock market over the recent years (Working paper series). Retrieved from http:// www.ipag.fr/wpcontent/uploads/recherche/WP/IPAG_WP_ 2014_230.pdf

Chandrapala, P., \& Knápková, A. (2013).Firm-specific factors and financial performance of firms in the Czech Republic. Acta Universitatis. Agriculturae et. Silviculturae. Mendelianae. Brunensis, 61(7), 2183-2190.

Chang, Y., \& Thomas, H. (1989). The impact of diversification strategy on risk-return performance. Strategic Management Journal, 10(3), 271-284.

Cheng, J. L. C., \& Kesner, I. F. (1997). Organizational slack and response to environmental shifts: The impact of resource allocation patterns. Journal of Management, 23(1), 1-18.

Coffee, J. C. (1988). Shareholders versus managers: The strain in the corporate web. In J. C. Coffee, L. Lowenstein \& S. Rose-Ackerman (Eds.), (pp. 314-354). New York: Knights, Raiders, and Targets. Oxford University Press. 
Cyert, R., \& March, J. G. (1963). A behavioral theory of the firm. Englewood Cliffs, NJ: Prentice-Hall.

Daniel, F., Lohrke, F. T., Fornaciari, C. J., \& Turner, R. A. (2004). Slack resources and firm performance: A meta-analysis. Journal of Business Research, 57, 565-574.

Davis, G. F., \& Stout, S. K. (1992). Organization theory and the market for corporate control: A dynamic analysis of the characteristics of large takeover targets, 1980-1990. Administrative Science Quarterly, 37(4), 605-633.

Dimson, E., \& Marsh, P. (1999). Murphy's Law and market anomalies. Journal of Portfolio Management, 26(2), 53-69.

Dimson, E., Marsh, P., \& Staunton, M. (2002). Triumph of the optimists. Princeton, New Jersey: Princeton University Press.

Fama, E. F. (1980). Agency problems and the theory of the firm. Journal of Political Economy, 88, 288-307.

Fama, E. F., \& French, K. R. (1992). The cross-section of expected stock returns. Journal of Finance, 47, 427-466.

Figenbaum, A., \& Thomas, H. (1985). An examination of the structural stability of bowman's risk-return paradox. Academy of Management Proceedings, 12, 7-11.

Figenbaum, A., \& Thomas, H. (1986). Dynamic and risk measurement perspectives on bowman's risk-return paradox for strategic management: An empirical study. Strategic Management Journal, 7(5), 395-407.

Figenbaum, A., \& Thomas, H. (1988). Attitudes toward risk and the risk-return paradox: Prospect theory explanations. The Academy of Management Journal, 31(1), 85-106.

Fisher, I. N., \& Hall, G. R. (1969). Risk and corporate rates of return. The Quarterly Journal of Economics, 83(1), 79-92.

Franck, T., Huyghebaert, N., \& D'espallier, B. (2010). How debt creates pressure to perform when information asymmetries are large: Empirical evidence from business start-ups. Journal of Economics \& Management Strategy (Winter), 19(4), 1043-1069.

Ghosh, A. (2001). Does accounting base performance really improve following corporate acquisitions? Journal of Corporate Finance, 7, 151-178.

Gomez-Mejia, L., \& Wiseman, R. M. (1997). Reframing executive compensation: An assessment and outlook. Journal of Management, 23, 291-375.

Hambrick, D. C., \& D'Aaveni, R. A. (1988). Large corporate failures as downward spirals. Administrative Science Quarterly, 33(1), 1-23.

Hansen, G. S., \& Wernerfelt, B. (1989). Determinants of firm performance: The relative importantance of economic and 
organizational factors. Strategic Management Journal, 10(5), 399411.

Harris, M., \& Raviv, A. (1991). The theory of capital structure. The Journal of Finance, 46(1), 297-355.

Hawawini, G., Subramanian, V., \& Verdin, P. (2003). Is firms' profitability driven by industry or firm-specific factors? A new look at the evidence, Strategic Management Journal, 24(1), 1-16.

Henkel, J. (2009). The risk-return paradox for strategic management: Disentangling true and spurious effects. Strategic Management Journal, 30, 287-303.

Hodoshima, J., Garza-Go'mez, X., \& Kunimura, M. (2000). Crosssectional regression analysis of return and beta in Japan. Journal of Economics and Business, 52, 515-533.

Horowitz, J. L., Loughran, T., \& Savin, N. E. (2000). Three analyses of the firm size premium. Journal of Empirical Finance, 7, 143-153.

Hurdle, G. J. (1974). Leverage, risk, market structure, and profitability. Review of Economics and Statistics, 56, 478-485.

Ismail, N., \& Subramaniam, A. (2017). Factors affecting performance of consumer products companies in Malaysia. Journal of Global Business and Social Entrepreneurship, 3(8), 12-19.I

Issah, M., \& Antwi, S. (2017). Role of macroeconomic variables on firms' performance: Evidence from the UK, Cogent Economics E Finance, 5, 1-18.

Jensen, M. C. (1986). Agency cost of free cash flow, corporate finance, and takeover. American Economic Review, 76, 323-329.

Jensen, M. C. (1989). Eclipse of the public corporation. Harvard Business Review, 67(5), 61-74.

Jensen, M. C., \& Meckling, W. H. (1976). Theory of the firm: Managerial behavior, agency costs and ownership structure. Journal of Financial Economics, 3(4), 305-360.

Kamasak, R. (2011). Firm-specific versus industry structure factors in explaining performance variation: Empirical evidence from Turkey. Management Research Review, 34(10), 1125-1146.

Kaya, E. O. (2015). The effects of firm-specific factors on the profitability of non-life insurance companies in Turkey. International Journal of Financial Studies, 3, 510-529.

Kipesha, E. F. (2013). Impact of size and age on firm performance: Evidence from Microfinance institutions in Tanzania. Research Journal of Finance and Accounting, 4(5), 105-116.

Kumar, J. (2004). Does corporate governance influence firm value? Evidence from Indian firms. The Journal of Entrepreneurial Finance and Business Ventures, 9(2), 61-93. 
Lee, S. (2011). How financial slack? Affects firm performance: Evidence from US industrial firms. Journal of Economic Research, 16, 1-27.

Li, X., Yang, F., \& Zhang, R. (2014). Determinants of corporate risk taking and risk-return relationship. Canadian Social Science, 10(2), 24-32.

Majumdar, S. K. (1997). The impact of size and age on firm-level performance: Some evidence from Indian industry. Review of Industrial Organization, 12, 231-241.

Markowitz, H. (1952). Portfolio selection. The Journal of Finance, 7(1), 77-91.

Markowitz, H. (1959). Portfolio selection--Efficient diversification of investments. New York: Wiley.

Marlin, D., \& Geiger, S. (2015). The organizational slack and performance relationship: A configurational approach. Management Decision, 53, 2339-2355.

McNamara, G., \& Bromiley, P. (1999). Risk and return in organizational decision-making. The Academy of Management Journal, 42(3), 330-339.

Miller, K. D., \& Leiblein, M. J. (1996). Corporate risk-return relations: Returns variability versus downside risk. The Academy of Management Journal, 39(1), 91-122.

Mohd Ali, H. (2006). Modern portfolio theory: Is there any opportunity for real estate? Malaysian Journal of Real Estate, 1(1), 14-26.

Mukherji, S., Dhatt, M. S., \& Kim, Y. H. (1997). A fundamental analysis of Korean stocks returns. Financial Analyst Journal, 53, 75-81.

Muritala, T.A. (2012). An empirical analysis of capital structure on firms' performance in Nigeria. International Journal of Advances in Management and Economics, 1(5), 116-124.

Opler, T. C., \& Titman, S. (1994). Financial distress and corporate performance, Journal of Finance, 49, 1015-1040.

Oviatt, B. M., \& Bauerschmidt, A. D. (1991). Business risk and return: A test of simultaneous relationships. Management Science, 37(11), 1405-1423.

Pervan, M., \& Višić, J. (2012). Influence of firm size on its business success. Croatian Operational Research Review, 3(1), 213-223.

Pfeffer, J., \& Salancik, G. R. (1978). The external control of organizations: a resource dependence perspective. New York: Harper and Row.

Phan, P., \& Hill, C. (1995). Organizational restructuring and economic performance in leveraged buyouts: An ex post study. Academy of Management Journal, 38, 704-739.

Reinganum, M. R. (1981). A new empirical perspective on the CAPM. Journal of Financial and Quantitative Analysis, 16, 439-462. 
Ritter, J. R. (2003). Behavioral finance. Pasific-Basin Finance Journal, $11,429-437$.

Roodman, D. (2006). How to do xtabond2: An introduction to "difference" and "system" center for global development working paper No. 103. Retrieved from http://www.nuffield.ox.ac.uk/users/bond/file_ HowtoDoxtabond8_with_foreword.pdf

Rossi, A., \& Timmermann, A. (2012). What is the shape of the riskreturn relation? Working Paper, University of California San Diego. Retrieved from http://financeseminars.darden.virginia. edu/Lists/Calendar/Attachments/132/Rossi_Timmermann_ Risk_Return.pdf

Saliha, T., \& Abdessatar, A. (2011). The determinants of financial performance: An empirical test using the simultaneous equations method. Economics and Finance Review, 10(1), 1-19.

Sang, K. K., Hyuksoo, C., \& Hinh, K. (2014). Slack and R\&D strategy: The effect of slack on internal R\&D and external R\&D, and innovation. Journal of Management Policy and Practice, 15(2), 3342. Retrieved from http://www.na businesspress.com/- JMPP/ KimSK_Web15_2_.pdf

Sargan, J. D. (1964). Wages and prices in the United Kingdom: A study in econometric methodology. In R. E. Hart, G. Mills, \& J. K. Whittaker (Eds.), Econometric analysis for national economic planning, Butterworth, London, 25-63.

Schwert, G. W. (2003). Anomalies and market efficiency. In G. M. Constantinides, M. Harris \& R. M. Stulz (Eds.), Handbook of the economics of finance. North Holland, Amsterdam. Retrieved from http://www.nber.org/papers/w9277.pdf

Serrasqueiro, Z. S., \& Maças Nunes, P. (2008). Performance and size: Empirical evidence from Portuguese ROASMEs. Small Business Economics, 31(2), 195-217.

Sharfman, M. P., Wolf, G., Chase, R. B., \& Tansik, D. A. (1988). Antecedents of organizational slack. Academy of Management Review, 13, 601-614.

Singh, J. V. (1986). Performance, slack, and risk taking in organizational decision-making. Academy of Management Journal, 20, 562-585.

Steensma, H. K., \& Corley, K. G. (2001).Organizational context as a moderator of theories on firm boundaries for technology sourcing. Academy of Management Journal, 44(2), 271-291.

Teece, D. J., Pisano, G., \& Shuen, A. (1997). Dynamic capabilities and strategic management. Strategic Management Journal, 18(7), 509533.

Tirole, J. (2001). Corporate governance. Econometrica, 69(1), 1-35. 
IJMS 25 (1), 83-104 (2018)

Tversky, A. (1990). The psychology of risk. Association of Investment Management and Research, 62-73.

Van Biesebroeck, J. (2005). Exporting raises productivity in subSaharan African manufacturing firms. Journal of International Economics, 67(2), 373-391.

Vintila, G., \& Nenu, E. A. (2015). An analysis of determinants of corporate financial performance: Evidence from the Bucharest Stock Exchange Listed Companies. International Journal of Economics and Financial Issues, 5(3), 731-739.

Whitelaw, R. F. (1994). Time variations and co-variations in the expectation and volatility of stock market return. The Journal of Finance, 49(2), 515-541.

Windmeijer, F. (2005). A finite sample correction for the variance of linear efficient two-step GMM estimators. Journal of Econometrics, 126, 25-517.

Wiseman, R. M., \& Bromiley, P. (1991). Risk-return association: Paradox or artifact? An empirically tested explanation. Strategic Management Journal, 12, 231-241.

Yang, C., \& Chen, L. (2009). On using organizational knowledge capabilities to assist organizational learning. In W. R. King, (Ed.) Knowledge management and organizational learning, annals of information systems 4 (pp. 303- 319). Boston, MA: Springer US.

Yu, G. J., \& Khessina, O. M. (2013). The role of exploration in firm survival in the worldwide optical library market, 1990-1998. Paper presented at the annual meeting of the Academy of Management.

Yurtoglu, B. B. (2004). Persistence of firm-level profitability in Turkey, Applied Economics, 36(6), 615-625. Retrieved from http://mackinstitute.wharton.upenn.edu/wp-content/ uploads/2013/04/Jea-Yu-Gun-Khessina-Olga_The-Role-ofExploration-in-Firm-Survival-in-the-Worldwide-OpticalLibrary-Market-1990-1998_v2.pdf 